\title{
Vai ir nepieciešamas karavīru arodbiedrības?
}

\author{
Ph.D. Vita Upeniece \\ Rīgas Stradina universitāte, Latvija \\ vita_up@yahoo.com
}

\section{Kopsavilkums}

Darba tiesības regulējošie normatīvie akti parasti satur noteikumu kopumu, kas regulē attiecības starp darbinieku apvienību vai darbinieku grupu un darba devēju. Biedrošanās brīvība ir nostiprināta arī vairākos starptautiskajos dokumentos, it ipaši ANO Cilvēktiesību deklarācijā, ANO Starptautiskajā paktā par pilsoniskajām un politiskajām tiesībām, ANO Starptautiskajā paktā par ekonomiskajām, sociālajām un kultūras tiesībām, Starptautiskās darba organizācijas 1948. gada Konvencijā par asociāciju brīvību un tiesību aizsardzību, apvienojoties organizācijās (C87) un 1949. gada Konvencijā par tiesībām uz apvienošanos organizācijās un kolektīvo līgumu slēgšanu (C98), kā arī Eiropas Cilvēktiesību konvencijā un Eiropas Sociālajā hartā. Vienlaikus starptautiskie dokumenti piel̦auj ierobežojumu noteikšanu nacionālajā regulējumā attiecībā uz karavīru arodbiedrību brīvību.

2018. gadā Latvijas Brīvo arodbiedrību savienība savā grāmatā aktualizēja jautājumu par atseviškłos dienestos, tostarp militārajā dienestā, esošo personu tiesību ierobežojuma apvienoties arodbiedrībās atcelšanu $[1,75]$. Raksta mērḳis: analizējot starptautisko un nacionālo regulējumu attiecībā uz arodbiedrību dibināšanu militārajā dienestā, kā arī Latvijā pašreiz pastāvošo karavīru tiesību aizsardzības sistēmu, izdarīt secinājumus par karavīru arodbiedrības izveidošanas lietderību.

Raksta sagatavošanā ir izmantota vēsturiskā, analītiskā, sistēmiskā un teleoloğiskā metode.

Atslēgvārdi: arodbiedrība, dienests bruṇotajos spēkos, sociālās garantijas.

\section{levads}

Daudzi starptautiskie dokumenti satur priekšnosacỉjumus, kuru dēl biedrošanās brīvība var tikt ierobežota. Starptautiskās darba organizācijas 1948. gada Konvencijas par asociāciju brīvību un tiesību aizsardzību, apvienojoties organizācijās (C87), 9. pants paredz, ka apjomu, kādā šajā konvencijā paredzētās garantijas attiecas uz bruṇotajiem 
spēkiem, nosaka valsts tiesību aktos [2]. Lìdzīgu nosacījumu satur arī 1949. gada Konvencijas par tiesībām uz apvienošanos organizācijās un kolektīvo līgumu slēgšanu (C98) 5. pants [3].

Atbilstoši ANO Starptautiskā pakta par pilsoniskajām un politiskajām tiesībām 22. panta otrajai daḷai tiesību uz asociāciju un arodbiedrību dibināšanas brīvību izmantošanā nav nekādu ierobežojumu, izṇemot tos, kas paredzēti likumā un kas demokrātiskā sabiedrībā nepieciešami valsts vai sabiedriskās drošības un sabiedriskās kārtības interesēs, iedzīvotāju veselības vai citu personu tiesību un brīvību aizsardzībai. Tālāk pantā ir noteikts, ka šie noteikumi netraucē paredzēt likumīgus ierobežojumus šo tiesību izmantošanā personām, kas ir bruṇoto spēku un policijas sastāvā [4]. ANO Starptautiskā pakta par ekonomiskajām, sociālajām un kultūras tiesībām 8. pantā noteikts, ka dalībvalstis apṇemas sekmēt katra cilvēka tiesības dibināt arodbiedrības savu ekonomisko un sociālo interešu sekmēšanai un aizsardzībai un iestāties tajās pēc paša izvēles, ievērojot vienīgi attiecīgās organizācijas noteikumus, un ka šĩs tiesības var izmantot bez jebkādiem ierobežojumiem, izṇemot tos, kuri paredzēti likumā un kas demokrātiskā sabiedrībā nepieciešami valsts drošības vai sabiedriskās kārtības interesēs vai citu juridisku vai fizisku personu tiesību un brīvību aizsardzībai [5].

Eiropas Cilvēktiesību un pamatbrīvību aizsardzības konvencijas 11. pants nostiprina jebkura cilvēka tiesības uz miermīlīgu pulcēšanās un biedrošanās brīvību, tostarp arodbiedrību dibināšanu un iestāšanos tajās savu interešu aizstāvībai. Vienlaikus šis pants paredz iespēju ierobežot iepriekšminētās tiesības ar likumu, ja tas ir nepieciešams demokrātiskā sabiedrībā valsts vai sabiedrības drošỉbas interešu aizstāvēšanai, nekārtîbu vai noziedzīgu nodarījumu nepiel̦aušanai, veselības vai tikumības vai citu cilvēku tiesību un brīvību aizsardzībai. Regulējums neliedz noteikt likumīgus ierobežojumus šo tiesību izmantošanā personām, kas ir bruṇoto spēku sastāvā [6]. Atbilstoši Eiropas Sociālās hartas 5. pantam, lai nodrošinātu vai veicinātu strādājošo un darba devēju tiesības brīvi veidot vietējās, nacionālās vai starptautiskās organizācijas, lai aizsargātu savas ekonomiskās un sociālās intereses un iestātos šajās organizācijās, dalībvalstis apñemas nodrošināt tādu nacionālo likumdošanu, kas neierobežotu, vai piemērot to tā, lai neierobežotu šīs tiesības. Vienlaikus šajā pantā ir noteikts, ka nacionālie normatīvie akti nosaka principus, saskaṇā ar kuriem šīs garantijas tiek piemērotas bruņoto spēku personālsastāvam, un apjomu, kurā tie attiecas uz personām, kas ietilpst šajā kategorijā [7].

Eiropas Sociālo tiesību komisija, vērtējot Eiropas Sociālās hartas 5. panta attiecināšanu uz bruṇotajiem spēkiem, norādīja, ka šo garantiju piemērošanas principus attiecībā uz bruṇoto spēku locekḷiem un to, cik lielā mērā tās attiecas uz šìs kategorijas personām, nosaka valsts normatīvie akti. Tādēl komisija vienmēr pārbauda, vai valsts tiesību aktos noteiktās struktūras, kas pieder pie brun,otajiem spēkiem, patiešām veic militāras funkcijas $[8,97]$. Valstis ir tiesīgas ierobežot biedrošanās tiesību izmantošanu karavīriem vai aizliegt to pilnībā $[9,51]$. Tādējādi komisija vērsa uzmanību, ka ierobežojumi var arī nebūt tādi, kas pilnībā aizliedz biedrošanās tiesības bruṇotajos spēkos. 
Hartas 5. pants l̦auj valstīm noteikt ierobežojumus bruṇoto spēku locekḷiem un piešḳir tām plašas vērtēšanas robežas, ievērojot Hartas $G$ pantu, ka jebkuriem ierobežojumiem jābūt noteiktiem likumā, tiem ir jābūt noteiktiem ar leğitīmu mērḳi un nepieciešamiem demokrātiskā sabiedrībā šì mērḳa sasniegšanai $[8,97]$.

Starptautiskā darba organizācija arī ir norādījusi, ka valstis var pašas lemt, vai piešķirt un cik lielā mērā būtu vēlams pieškịtrt bruṇotajiem spēkiem Starptautiskās darba organizācijas 1948. gada Konvencijā par asociāciju brīvību un tiesību aizsardzību, apvienojoties organizācijā (C87), paredzētās tiesības [10, 64].

Tādējādi tiesības biedroties vai apvienību un asociāciju brīvība ir viena no cilvēka pamattiesībām. Tomēr valstu attieksme pret šìs tiesības garantēšanu brun,otajos spēkos kā valsts izveidotā institūcijā, kuras primārais mērḳis ir valsts aizsardzība no ārējiem apdraudējumiem un iekšējiem konfliktiem, ir atškirīga. [11, 70].

\section{Tiesību dibināt karavīru arodbiedrības izmantošanas problemātika}

Valstis, kuras ir aizliegušas veidot karavīru arodbiedrības, biedrošanās tiesību ierobežošanu pamato pārsvarā ar militārās disciplīnas pazemināšanās risku un ar to saistīto negatīvo ietekmi uz operacionālajām spējām un nacionālo drošỉbu [11, 70].

Lai izvairītos no militārās disciplīnas pazemināšanās riska un ar to saistītās negatīvās ietekmes uz operacionālajām spējām un nacionālo drošību, valstis, kuras ir devušas iespēju karavīriem veidot arodbiedrības, pārsvarā nosaka šādus ierobežojumus:

1) pārstāvības organizācija sastāv tikai no bruṇoto spēku locekḷiem un nav saistīta ar civilām arodbiedrībām, lai izvairītos no jebkādas ārējas ietekmes;

2) nav atḷauti streiki vai citas līdzvērtīgas darbības, kas potenciāli varētu sagraut operacionālās spējas vai apdraudēt valsts drošību [11, 71-72].

Eiropas Sociālo tiesību komisija lietā Eiropas militāro asociāciju organizācija pret İiju, atzīstot policijas tiesības uz streikiem kā vienu no kolektīvo pārrunu tiesības pamatelementiem, kuru nosaka Eiropas Sociālās hartas 6. pants un bez kura šīs tiesības saturs zaudē savu būtību un līdz ar to arī savu efektivitāti [12], neatzina brun,oto spēku pārstāvju tiesības streikot. İrijas valdība šajā lietā uzsvēra, ka streika būtība nav savietojama ar bruṇoto spēku lomu un tiesības uz streiku aizliegšana ir pamatota ar nepieciešamību novērst bruṇoto spēku destabilizēšanu ar protesta kustībām. Pat tad, ja bruṇoto spēku organizācijām būtu aț̣auts brīvprātīgi piedalīties streikos, šādos pasākumos to locekḷi būtu atvērti ārējās ietekmes vai mērḳu un politikas sadursmes riskam, jo civilās iestādes var lūgt brun,oto spēku atbalstu valstĩ notiekošo piketu vai streiku gadījumos un var rasties situācijas, kad bruṇotajiem spēkiem jāšķērso piketētāju līnija [13, 35.-38. S].

Eiropas Sociālo tiesību komisija iepriekšminētajā lietā uzsvēra, ka tiesības streikot ir visefektīvākais līdzeklis, lai panāktu labvēlīgu rezultātu sarunu procesa rezultātā. Tāpēc šìs tiesības ir īpaši nozīmīgas arodbiedrībām. Līdz ar to šo tiesību ierobežojumi var būt piel̦aujami tikai ar ìpašiem nosacījumiem. Izvērtējot jautājumu par streikošanas 
tiesību aizliegšanu bruṇoto spēku pārstāvjiem, komisija konstatēja, ka šādam ar likumu noteiktam ierobežojumam ir leǵitīms mērḳis - uzturēt sabiedrisko kārtību, nacionālo drošību un citu tiesības un brīvības, nodrošinot, ka brun,otie spēki ir pilnībā darboties spējīgi un vienmēr pieejami.

Vērtējot, vai ar aizliegumu bruṇotajiem spēkiem streikot tiek sasniegts demokrātiskas sabiedrības likumīgais mērḳis, komisija secināja, ka šì novērtējuma robeža ir būtiskāka nekā tā, kas ir noteikta valstīm attiecībā uz policiju. Tādēl, ņemot vērā bruṇoto spēku uzdevumu īpašo raksturu, bruṇoto spēku darbību saskaṇā ar militārās disciplīnas sistēmu, potenciālu, ka jebkura rūpnieciska darbība (industrial action) varētu izjaukt operācijas tādā veidā, kas apdraud valsts drošību, komisija atzina, ka ir pamats tam, lai likumā tiktu noteikts absolūtais aizliegums attiecībā uz tiesībām streikot. Šāds aizliegums ir proporcionāls noteiktajam likumigajam mērḳim, tādēḷ to var uzskatìt par nepieciešamu demokrātiskā sabiedrībā. Komisija atzina, ka aizliegums bruṇotajiem spēkiem streikot nepārkāpj Eiropas Sociālās hartas 6. panta 4. punktu [13, 111.-118. \$].

\section{Tiesību ierobežojums dibināt karavīru arodbiedrību nacionālajā regulējumā}

Atbilstoši Latvijas Republikas Satversmes 108. pantam valsts aizsargā arodbiedrību brīvību. Vienlaikus Latvijas Republikas Satversmes 116. pants paredz iespēju ierobežot šo brīvību likumā paredzētajos gadījumos, lai aizsargātu citu cilvēku tiesības, demokrātisko valsts iekārtu, sabiedrības drošību, labklājību un tikumību [14]. Militārā dienesta likuma 15. panta pirmās daḷas 1. punkts nosaka, ka karavīram ir aizliegts veikt politisko darbību, pievienoties arodbiedrībām, organizēt streikus un piedalïties tajos [15].

Nacionālie bruṇotie spēki (turpmāk - NBS) ir militāro formējumu kopums, kuru veido militāri organizēta, apmācīta un apbruṇota tautas daḷa. To mērḳis ir aizsargāt Latvijas valsts suverenitāti, teritoriālo nedalāmību un tās iedzīvotājus no agresijas [16, 2. pants]. Tādējādi NBS îsteno vienu no valsts funkcijām - valsts aizsardzību, kas ir būtiska valsts suverēnās varas joma. No šĩs funkcijas efektīvas īstenošanas ir atkarīga valsts drošība. Tādēl dienesta tiesiskais regulējums interpretējams, n,emot vērā šā dienesta lomu valsts

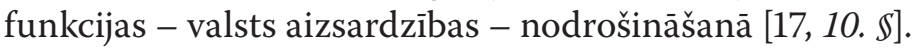

Militārā dienesta likumā ir nostiprināts katra karavīra pienākums ievērot militāro disciplīnu - normatīvajos aktos un ar komandiera pavēlēm noteikto kārtību [15, 6. pants]. Atbilstoši Militārā dienesta likuma 2. panta 4. punktam profesionālais dienests ir militārais dienests, kuru Latvijas pilsonis pilda brīvprātīgi saskaņā ar profesionālā dienesta līgumu. Noslēdzot profesionālā dienesta līgumu, tiek nodibinātas militārā dienesta tiesiskās attiecības, kur karavīrs atrodas īpašã valsts pakḷautībā - NBS rīcībā. Militārā dienesta attiecību būtiskākā atškiriība no citiem valsts dienesta veidiem ir to pamatā esošās valsts imperatīvās militārās intereses, kas vērstas uz valsts pastāvēšanas un suverenitātes nodrošināšanu. Šo vitāli svarīgo valsts interešu efektīva nodrošināšana ir pamatā tam, ka militārajā dienestā būtiska nozīme tiek piešķirta karavīra norīkošanai atbilstoši dienesta 
vajadzībām, ņemot vērā konkrētā karavīra specialitāti un vadības vērtējumu par karavīra specialitātes atbilstību konkrētajai amata vietai (sk. Militārā dienesta likuma 21. panta pirmo daḷu, 25. panta trešo daḷu) [17, 12. S]. Augstākās tiesas Senāta Administratīvo lietu departaments 2012. gada 4. jūnija spriedumā lietā $S K A-138 / 2012$ pievienojās secinājumam, ka militārajam dienestam ir savas ievērojamas īpatnības, kas to atškir no civildienesta $[18,154]$.

Ir arī jāṇem vērā, ka atbilstoši Militārā dienesta likuma 12. panta pirmajai un otrajai dal̦ai karavīrs ir valsts aizstāvis, kas savas tiesības uz darbu realizē, pildot militāro dienestu, un uz karavīru ar atseviškiem izṇēmumiem neattiecas darba tiesiskās attiecības reglamentējošo normatīvo aktu normas [15]. Proti, Valsts un pašvaldību institūciju amatpersonu un darbinieku atlīdzības likumā viṇam nav paredzēta samaksa par virsstundu darbu, nakts darbu un darbu nedēḷas atpūtas un svētku dienās. Tomēr jāatzīmē, ka atrašanās aktīvajā dienestā nenozīmē nepārtrauktu amata pienākumu izpildi. Atbilstoši Aizsardzības ministrijas (turpmāk- AM) 2012. gada 3. augusta noteikumu Nr. 21-NOT "Militārā dienesta iekārtas reglaments" (turpmāk - reglaments) 179. punktam karavīram dienā pēc iespējas nodrošina astoṇu stundu dienests, savukārt pirmssvētku dienās - par vienu stundu îsāks dienests, izṇemot norīkojumus, ārkārtas uzdevumus un dalību mācībās vai kursos, kad tas var tikt noteikts ilgāks par astoṇām stundām. Reglamenta 180. punktā noteikts, ka komandieris piešḳir karavīram atbrīvojumu no dienesta pienākumiem (brīvdienu) atbilstoši laikam, ko karavīrs ir pavadījis dienestā brīvdienās (sestdienā un svētdienā) un svētku dienās, izṇemot atseviškłus reglamentā noteiktos gadījumus [19]. Militāro dienestu raksturojošā īpatnība ir arī karavīra pienākums bez ierunām pildīt komandiera likumīgās pavēles un karavīra paḳ̣aušana stingrai militārai disciplīnai $[15$, 4. panta pirmā dalı, 6. pants, 7. panta otrā dalı].

Vienlaikus karavīriem ir nodrošināts plašs sociālo garantiju klāsts. Militārpersonu izdienas pensiju likums paredz izdienas pensijas maksāšanu no profesionālā dienesta atvaḷinātajiem karavīriem, lai palīdzētu tiem veiksmīgi integrēties civilajā dzīvē [24]. Lai sniegtu atbalstu NBS starptautisko operāciju veterāniem, AM 2011. gadā uzsāka akciju, mudinot uzṇēmējus piedāvāt īpašas atlaides to precēm un pakalpojumiem. Šai akcijai atsaucās vairāki uzṇēmēji [25].

Karavīriem nav noteikts absolūtais aizliegums pārstāvēt un aizsargāt savas intereses. Karavīram ir tiesības būt par biedru tādās biedrībās un nodibinājumos, kurām nav politiska rakstura, kā arī dibināt karavīru biedrības un nodibinājumus un piedalīties citos nepolitiskos pasākumos, ja šāda darbība netraucē dienesta pienākumu izpildi $[15,10$. panta otrā un trešā daḷ]. Pašlaik darbojas vairākas nevalstiskās organizācijas (piemēram, Latviešu virsnieku apvienība, Latvijas Rezerves virsnieku asociācija, Latvijas Nacionālo karavīru biedrība, Latvijas Nacionālo partizānu apvienība, Latviešu strēlnieku apvienība, Latvijas armijas veterānu asociācija u. c.), kuras ne tikai aizstāv savu biedru un viṇu g̣imenes locekḷ tiesības un intereses, bet arī, komunicējot ar valsts institūcijām, aktualizē citus jautājumus aktīvajā dienestā esošo un atvaḷināto karavīru sociālo un citu garantiju jomā. 
Karavīriem ir arī tiesības katrā vienībā no sava vidus izvirzìt pārstāvi karavīru interešu aizstāvēěanai un sadzīves jautājumu risināšanai attiecībās ar vienības komandieri (priekšnieku) un augstākām amatpersonām $[15,10$. panta trešā daḷa].

Karavīru pārstāvju kompetencē ietilpst jautājumi, kas saistīti ar:

- veselības aprūpes un drošỉbas pasākumu ievērošanu;

- sociālo labklājību;

- atvalinājumiem un brīvo laiku;

- dienesta un sadzives apstākḷu uzlabošanu;

- attiecību uzlabošanu vienības karavīru vidū;

- attiecību uzlabošanu starp vienību karavīriem un vietējiem iedzìvotājiem [19].

Reglamenta 357. punktā uzsvērts, ka karavīru pārstāvju kompetencē neietilpst jautājumi, kas saistīti ar militārā dienesta pienākumu izpildi, kā arī operatīvie un politiskie jautājumi [19], jo NBS pamatfunkciju izpildes pārtraukšana vai traucēšana var kaitēt efektīvai valsts mērḳu - demokrātiskas valsts iekārtas, valsts drošības, valsts pastāvēšanas un suverenitātes - îstenošanai.

Reglamentā ir paredzēta iespēja karavīram iesniegt dienesta sūdzību par apgādes saṇemšanas un sociālo garantiju nodrošināšanas jautājumiem [19]. Arī AM struktūrvienība G̦enerālinspekcija veic dienesta pārbaudes un izskata karavīru sūdzības un ierosinājumus, lai noskaidrotu dienesta apstākḷus un sociālo jautājumu atbilstību noteiktajām prasībām, kā arī pārbauda disciplinārsodu uzlikšanas kārtības ievērošanu, nepieciešamības gadījumā konsultējot karavīrus ar normatīvajiem aktiem noteikto tiesību aizsardzībai. Militārā dienesta likuma 10. panta ceturtā daḷa paredz karavīram tiesības pārsūdzēt tiesā attiecībā uz viṇu pien̦emtos amatpersonu lēmumus, ja tie nepamatoti ierobežo viņa tiesības vai aizskar viṇa godu un cieṇu [15]. Sūdzību izskatīšanai par uzliktajiem disciplinārsodiem AM ir izveidota Apelācijas komisija, kuras lēmumu karavīrs var pārsūdzēt tiesā $[20,21]$.

Jāatzīmē, ka ikviens var iesaistìties normatìvo aktu projektu satura tapšanas procesā, sniedzot priekšlikumus par Ministru kabineta un AM mājaslapā pirms uzsaukšanas Valsts sekretāru sanāksmē sabiedrības līdzdalības nodrošināšanai publicētajiem ārējiem normatīvajiem aktiem [22, 5. punkts]. Saeimas kārtības rullī ir paredzētas iespējas vēlētājiem izteikt deputātiem mutvārdu vai rakstveida ierosinājumus un sūdzības [23, 196. pants]. Tiek rīkotas Saeimas Aizsardzības, iekšlietu un korupcijas novēršanas komisijas izbraukuma sēdes NBS vienībās, kuru laikā tiek apspriesti aktuāli aizsardzības resora jautājumi, kā arī notiek iepazī̌anās ar NBS procesā esošajiem projektiem. Tādējādi karavīri var iesaistīties normatīvo aktu projektu satura tapšanā.

Jāsecina, ka streiku pieteikšanas (tā tiek uzskatīta par efektīvu līdzekli spēku nevienlīdzības izlīdzināšanā darbinieka un darba devēja starpā $[26,77])$ absolūts aizliegums nacionālajā līmenī ir pamatots, jo bruṇotajiem spēkiem ir jānodrošina pastāvīga un nepārtraukta valsts aizsardzība. Pastāvošais ierobežojums karavīru pārstāvjiem iejaukties militārā dienesta pienākumu izpildes jautājumos, tāpat kā pilnvarojuma neesamība pārstāvjiem iejaukties militārās disciplīnas jautājumos ir arī attaisnojama, jo šādas 
darbības mazinās bruṇoto spēku uzdevumu izpildes efektivitāti. Arī Satversmes tiesa 2014. gada 23. aprīla spriedumā lietā Nr. 2013-15-01 11. punktā ir atzinusi, ka tādām brīvības īstenošanas procesuālajām izpausmēm, kā, piemēram, tiesībām organizēt streikus un piedalīties tajos, arodbiedrību iespējamai ietekmei uz dienesta gaitu vai līdzdalïbai disciplinārās atbildības jautājumu risināšanā var būt ietekme uz valsts vai sabiedrības drošības interesēm [27].

Savukārt militārpersonu arodbiedrības izveidošanas ierobežojums nacionālajā regulējumā ir kompensēts ar iespēju karavīriem izvirzìt no sava vidus pārstāvi karavīru interešu aizstāvēšanai komunikācijā ar aizsardzības resora vadību sadzīves jautājumu risināšanai un savu interešu aizstāvībai. Karavīram ir tiesības būt par biedru tādās biedrībās un nodibinājumos, kuriem nav politiska rakstura, kā arī dibināt karavīru biedrības un nodibinājumus un piedalīties citos nepolitiskos pasākumos, ja šāda darbība netraucē dienesta pienākumu izpildi. Karavīram ir paredzēta iespēja iesniegt dienesta sūdzību NBS vai vērsties ar sūdzību, kā arī saṇemt konsultāciju no struktūrvienības, kas ir neatkarīga no NBS, - no AM G̦enerālinspekcijas. Pastāv efektīvs disciplinārsodu tiesiskuma izvērtēšanas mehānisms, kuru nodrošina gan AM G̦enerālinspekcija, gan AM Apelācijas komisija. Karavīram ir tiesības iesniegt sūdzību tiesā, tostarp konstitucionālu sūdzību Satversmes tiesā. NBS tiek aktīvi iesaistīti ārējo un iekšējo normatīvo aktu izstrādē. Karavīri var izteikt ierosinājumus ārējo normatīvo aktu satura uzlabošanai sabiedrības līdzdalības procesā, kā arī iesniegt deputātiem priekšlikumus vai ierosinājumus.

Tādējādi nacionālā līmenī ir izveidoti efektīvi mehānismi militārpersonu interešu aizstāvībai un pārstāvībai. Arodbiedrības izveidošana, ja tā tiktu aț̣auta, daudzos jautājumos dublētu pastāvošo kārtību. Savukārt ierobežojumu noteikšana attiecībā uz darbībām, kuras varētu kavēt vai iejaukties bruṇoto spēku disciplīnas nodrošināšanas jautājumos un uzdevumu izpildē, nepiel̦aus efektīvu līdzekḷu izmantošanas iespējas darba devēja ietekmēšanai. Tādēḷ militārās arodbiedrības darbības efektivitāte būtu diskutējama.

\section{Secinājumi}

1. Starptautiskie cilvēktiesību dokumenti neaizliedz noteikt ierobežojumus arodbiedrību izveidošanai bruṇotajos spēkos dienošajām personām.

2. Arodbiedrības kā neatkarīgas institūcijas darbības mērḳis ir novērst un reageèt uz slikto pārvaldi un cilvēktiesību pārkāpumiem, izskatot sūdzības. Šis ir būtisks demokrātiskas sabiedrības pastāvēšanas mērḳis, kurš nacionālajā līmenī ir sasniegts ar šādām karavīru tiesībām:

1) tiesībām izvirzīt no sava vidus pārstāvi savu interešu aizstāvēšanai komunikācijā ar aizsardzības resora vadību sadzīves jautājumu risināšanai un savu interešu aizstāvībai;

2) tiesībām būt par biedriem tādās biedrībās un nodibinājumos, kuriem nav politiska rakstura, kā arī dibināt karavīru biedrības un nodibinājumus un piedalīies citos nepolitiskos pasākumos, ja šāda darbība netraucē dienesta pienākumu izpildi; 
3) tiesībām iesniegt dienesta sūdzību Nacionālajos bruṇotajos spēkos vai vērsties ar sūdzību, kā arī saṇemt konsultāciju no struktūrvienības, kas ir neatkarīga no Nacionālajiem brun,otajiem spēkiem, - no Aizsardzības ministrijas G̦enerālinspekcijas;

4) tiesībām apstrīdēt disciplinārsodus Aizsardzības ministrijas Apelācijas komisijā un tās lēmumu pārsūdzēt tiesā, kā arī tiesībām apstrīdēt Aizsardzības ministrijā citus administratīvos aktus un pārsūdzēt Aizsardzības ministrijas lēmumus tiesā, tostarp tiesībām iesniegt konstitucionālu sūdzību Satversmes tiesā;

5) tiesībām iesaistīties ārējo un iekšējo normatīvo aktu izstrādē. Nacionālie bruṇotie spēki aktīvi iesaistās ārējo un iekšèjo normatīvo aktu izstrādē. Karavīri var izteikt ierosinājumus ārējo normatīvo aktu satura uzlabošanai sabiedrības līdzdalības procesā, kā arī iesniegt deputātiem priekšlikumus vai ierosinājumus.

3. Ir pamatots nacionālajā regulējumā nostiprinātais absolūtais aizliegums streikot, jo bruṇotajiem spēkiem ir jānodrošina pastāvīga un nepārtraukta valsts aizsardzība.

4. Arodbiedrības ietekmes iespējas nosaka tās resursi un piešḳirtā vara. Tā kā tiesības uz streiku ir efektīvs līdzeklis vēlamā rezultāta panākšanai, to aizliegums būtiski samazina arodbiedrības ietekmes iespējas.

5. Ievērojot iepriekš minēto, nav pārliecības, ka karavīru arodbiedrības darbība būtu efektīvāka par 2. punktā minēto nacionālajā līmenī nodibināto karavīru interešu un tiesību aizsardzības sistēmu.

\section{Are Military Unions Necessary?}

\section{Abstract}

The right to freedom of association is embodied in a number of international treaties, such as the Universal Declaration of Human Rights, the International Covenant on Civil and Political Rights, the International Covenant on Economic, Social and Cultural Rights, the Freedom of Association and Protection of the Right to Organise Convention (1948) No. 87, the Right to Organise and Collective Bargaining Convention (1949) No. 98, the European Convention on Human Rights and the European Social Charter. Simultaneously, the international treaties allow for a restriction on the freedom of military trade unions in the national regulation.

In 2018, the issue of restriction of the right of soldiers to unite in trade unions was raised in Latvia in the book published by the Latvian Free Trade Union $[1,75]$. The article examines the international and national regulation applicable to this issue, the current 
national system and procedures which are established for the protection of the rights of soldiers and concludes by expressing opinion about the need to establish a military trade union in Latvia.

In the Author's opinion, existing restriction on the establishment of a military trade union in the national regulation is compensated by the following rights:

1) the right to nominate a representative from among themselves to defend the interests of soldiers for the defense of their interests and settlement of household issues;

2) the right to be a member of associations and foundations of a non-political nature, as well as to establish military associations and foundations and to participate in other non-political activities, if such activity does not interfere with the performance of the duties of the service;

3) the right to lodge a service complaint within the framework of the National Armed Forces and to apply a complaint, as well as to receive a consultation from a structural unit which is independent of the National Armed Forces the General Inspection of the Ministry of Defense;

4) the right to submit a complaint to a court, including a constitutional complaint to the Constitutional Court;

5) there is an effective mechanism for evaluating and controlling observance of law of disciplinary measures provided by both the General Inspection of the Ministry of Defense and the Appeal Commission of the Ministry of Defense;

6) the National Armed Forces are actively involved in the development of external and internal regulation. In addition, soldiers may make proposals to improve the content of the projects of external regulations within the framework of the public participation process, as well as by submitting proposals or suggestions to deputies.

Although the application of strikes is considered to be an effective mean of leveling out the inequality of power between the employee and the employer, the prohibition of strikes among the military personnel is justified because the armed forces have the task of providing permanent and uninterrupted national defense. The existing restriction on military representatives to intervene in the performance of military service duties, as well as the lack of authorisation for military representatives to intervene in matters of military discipline, are reasonable restrictions, as such actions would reduce the effectiveness of the tasks of the armed forces. The Constitutional Court of Latvia also recognised that procedural manifestations of the exercise of freedom, such as the right to organise and participate in strikes and the possible influence of trade unions on the conduct of the service or participation in disciplinary liability issues, may have an impact on the State or public safety interests.

Thus, the Author concludes that effective mechanisms have been established for the protection and representation of the interests of the soldiers. If the creation of a military trade union was allowed, it would duplicate the existing procedures on many issues. 
The imposition of restrictions on activities that could hinder or interfere in the issues of the discipline liability and in the performance of tasks of the armed forces will exclude effective means of influencing the employer. Therefore, the effectiveness of such unions would be debatable.

Keywords: military service duties, trade unions, military trade union, social guarantees.

\section{Avoti un literatūra}

1. Liepina, I., Preisa, N., Rācenājs, K. 2018. Arodbiedrību ekskluzìvās tiesības un koplïgumu pārrunu brivīiba. Freidrich Ebert Stiftung, Latvijas brīvo arodbiedrïbu savienība.

2. Konvencija par asociāciju brīvību un tiesību aizsardzību, apvienojoties organizācijās (C87). 09.07.1948. Iegūts no: https://ikumi.lv/ta/lv/starptautiskie-ligumi/id/646

3. Konvencija par tiesībām uz apvienošanos organizācijās un kolektīvo līgumu slēgšanu (C98). 01.07.1949. Iegūts no: https://likumi.lv/ta/lv/starptautiskie-ligumi/id/677

4. Starptautiskais pakts par pilsoṇu un politiskajām tiesībām. 16.12.1966. Iegūts no: https://likumi. lv/ta/lv/starptautiskie-ligumi/id/705

5. International Covenant on Economic, Social and Cultural Rights. 16.12.1966. Iegūts no: https:// www.ohchr.org/EN/professionalinterest/pages/cescr.aspx

6. Cilvēka tiesību un pamatbrīvību aizsardzības konvencija. 04.11.1950. Iegūts no: https://likumi. $\mathrm{lv} / \mathrm{ta} / \mathrm{lv} /$ starptautiskie-ligumi/id/649

7. Eiropas Sociālā harta. 18.10.1961. Iegūts no: https://ikumi.lv/ta/lv/starptautiskie-ligumi/id/1045

8. Digest of the Case Law of the European Committee of Social Rights. 2018. Iegūts no: https:// rm.coe.int/digest-2018-parts-i-ii-iii-iv-en/1680939f80

9. Digest of the Case Law of the European Committee of Social Rights. 2008. Iegūts no: https:// www.refworld.org/docid/4a3f52482.html

10. Freedom of Association. Compilation of decisions of the Committee on Freedom of Association. $6^{\text {th }}$ ed. 2018. International Labour Office - Geneva. Iegüts no: https://www.ilo.org/wcmsp5/ groups/public/---ed_norm/---normes/documents/publication/wcms_632659.pdf

11. Handbook on Human Rights and Fundamental Freedoms of Armed Forces Personnel. 2008. Warsaw: OSCE Office for Democratic Institutions and Human Rights (ODHIHR). Iegūts no: https://www.osce.org/odihr/31393?download=true

12. Decision of the Committee of Social Rights. Complaint No. 83/2012. European Confederation of Police (EuroCOP) v. Ireland. 02.12.2013. https://hudoc.esc.coe.int/ eng/\#;“fulltext”:[“EuroCOP”], "ESCDcType":[“FOND”,"Conclusion","Ob”],"ESCDcIdentifier": ["cc-83-2012-dadmissandmerits-en"]\}

13. Decision of the Committee of Social Rights. Complaint No. 112/2014, European Organisation of Military Associations (EUROMIL) v. Ireland. 12.09.2017. Iegūts no: https://hudoc.esc.coe.int/ eng/\#;“fulltext”:[“(EUROMIL)vIreland”],"ESCDcIdentifier”:[“cc-112-2014-dmerits-en”],"ESCDc Type":[“FOND","Conclusion","Ob”]\}

14. Latvijas Republikas Satversme: Latvijas Republikas likums: piennemta Satversmes sapulcē 1992. gada 15. februārī un stājās spēkā 1992. gada 7. novembrī. Latvijas Vēstnesis. 43, 01.07.1993.

15. Militārā dienesta likums: Latvijas Republikas likums. Latvijas Vēstnesis. 91, 18.06.2002. 
16. Nacionālo bruṇoto spēku likums: Latvijas Republikas likums. Latvijas Vēstnesis. 388/389, 24.11.1999.

17. Augstākās tiesas Senāta administratīvo lietu departamenta spriedums lietā Nr. SKA - 138/2012. 04.06.2012. Iegūts no: http://at.gov.lv/lv/judikaturas-nolemumu-arhivs-old/senata-administrativo-lietu-departaments/hronologiska-seciba/2012

18. Dišlers, K. 2002. Ievads administratìvo tiesību zinātnē. Rīga: Tiesu namu aǵentūra.

19. Militārā dienesta iekārtas reglaments: Aizsardzības ministrijas noteikumi Nr. 21-NOT. 03.08.2002.

20. Karavīru un zemessargu militārās disciplīnas reglaments: Ministru kabineta noteikumi Nr. 947. Latvijas Vēstnesis. 163, 14.10.2010.

21. Likumprojekts "Militārās diciplināratbildības likums". Iegūts no: https://titania.saeima.lv/ LIVS13/SaeimaLIVS13.nsf/webAll?SearchView\&Query=([Title]="disciplināratbildỉbas+likum $\left.S^{*}\right) \&$ SearchMax $=0 \&$ SearchOrder $=4$

22. Sabiedrības lïdzdalības kārtība attīstības plānošanas procesā: Ministru kabineta noteikumi Nr. 970. Latvijas Vēstnesis. 141, 04.09.2009.

23. Saeimas kārtības rullis: Latvijas Republikas likums. Latvijas Vēstnesis. 96, 18.08.1994.

24. Militārpersonu izdienas pensiju likums: Latvijas Republikas likums. Latvijas Vēstnesis. 86, 01.04.1998.

25. Nacionālie Bruṇotie spēki. Uzṇēmēju atbalsts karavĩriem. Iegūts no: https://www.mil.lv/lv/ aktivais-dienests/atbalsts-karaviriem/uznemeju-atbalsts-karaviriem

26. Mickeviča, N., Rācenājs, K. 2015. Arodbiedrību likums ar komentāriem. Latvijas brīvo arodbiedrību savienība.

27. Latvijas Republikas Satversmes tiesas spriedums lietā Nr. 2013-15-01. 23.04.2014. Iegūts no: https://www.satv.tiesa.gov.lv/web/viewer.html?file=/wp-content/uploads/2016/02/2013-15-01_ Spriedums.pdf\#search= 